\title{
CONCEPTS AND METHODS OF MATHEMATIC MODELLING OF PLANT GROWTH AND DEVELOPMENT. PLANT GERMINATION -PART I
}

\author{
Sławomir Kocira* \\ Department of Machinery Exploitation and Management of Production Processes, \\ University of Life Sciences in Lublin, Lublin, Poland
}

${ }^{*}$ Corresponding author:email: slawomir.kocira@up.lublin.pl

\begin{tabular}{|c|c|}
\hline ARTICLE INFO & ABSTRACT \\
\hline $\begin{array}{l}\text { Article history: } \\
\text { Received: June } 2018 \\
\text { Received in the revised form: } \\
\text { August } 2018 \\
\text { Accepted: September } 2018\end{array}$ & \multirow{2}{*}{$\begin{array}{l}\text { Contemporary agricultural engineering searches for "safe" methods of } \\
\text { raising crop yields, using a combination of knowledge from a number } \\
\text { of sciences. Thus, computer modelling of plant growth and develop- } \\
\text { ment fits this range, because it has become an area of interdisciplinary } \\
\text { research. Presentation of knowledge in the form of mathematical } \\
\text { computer models is one of paradigms of agricultural production } \\
\text { systems based on the scientific and practical knowledge and infor- } \\
\text { mation. In the scientific activity concerning agricultural engineering } \\
\text { research tasks related to mathematical modelling of agrobiological } \\
\text { processes have been carried out for many years. Additionally, the use } \\
\text { of modern forecasting techniques in agriculture may bring real finan- } \\
\text { cial advantages with regard to the fact that based on crop yield predic- } \\
\text { tion estimation of their cultivation profitability is possible. Dynamic } \\
\text { and continuous progress of computer and informative technologies } \\
\text { creates new opportunities showing thus growth directions of agricul- } \\
\text { tural engineering. Taking this into consideration, it should be empha- } \\
\text { sised that mathematical modelling constitutes a support for decision } \\
\text { processes which take place in agricultural production. This article } \\
\text { discusses mathematical models, where the analysed system is de- } \\
\text { scribed with the use of mathematical formulas. The objective of the } \\
\text { paper was to present the current state of knowledge on mathematical } \\
\text { methods in describing and predicting seeds germination. Possibilities } \\
\text { of their use and new challenges which occur in the description of } \\
\text { seeds germination were presented. }\end{array}$} \\
\hline $\begin{array}{l}\text { Key words: } \\
\text { modelling in agriculture } \\
\text { computer simulations, } \\
\text { mathematical modelling, germination }\end{array}$ & \\
\hline
\end{tabular}

\section{Introduction}

Modern agricultural engineering searches for "safe" methods of raising the quality of crop yields with the use of an interdisciplinary combination of mathematics, biophysics, agronomy, molecular biology and physics (Cieśla et al., 2015). Research tasks, including mathematical modelling of agribiological processes are performed as a part of agricultural engineering and its current activity (Michałek, 2008). Since, application of modern prediction methods in agriculture may bring notable financial advantages. Mathematical modelling answers the challenges related thereto. Representation of knowledge in the form of 
computer models is one of paradigms of agricultural production systems based on knowledge. Modelling enables fast, often automated transformation of expert knowledge in the form of computer models. On the other hand, the quality of models depends on the knowledge quality, not only the theoretical one, but also practical, and thus computer models should be made by specialists in this field (Maksym et al., 2006).

The model is a simplified representation of the system and the system is a limited part of the reality, which includes elements combined together (de Wit, 1982, Prusinkiewicz, 2004). Mathematical models will be discussed in the article, where the analysed system is described with the use of mathematical models.

Generally, models may be divided into static (describing plants in a specific growth stage) or developmental ones (that describe plants during their growth). From among models of a developmental nature their two types need special attention i.e descriptive (the socalled reconstruction) and mechanistic ones. Descriptive models constitute a tool that supports integration of results of measurements in time. While, mechanistic ones, in their assumptions, constitute an attempt to explain plant growth based on the basis of processes: biological, chemical and physical. In case of growth models we deal with calculation and simulation research.

Despite numerous publications which describe the plant growth and development processes, still there is no agreement as to the value and usefulness of calculation models in developmental biology or agriculture. The discussion concerns mainly the possibilities of application of research methods, including mathematical deduction, to the data with biological nature (Keller, 2002). However, despite a low number of negative opinions, it is estimated that modelling and simulation constitute and will constitute one of the most important elements in the description and prediction of plant growth and development (Room et al. 1996; Minorsky, 2003; Niklas, 2003). Thanks to calculation models, it is possible to understand growth mechanisms such as e.g. a detailed description of the plant growth dynamics in a quantitative manner. Computer modelling of plant growth and development has become an area of interdisciplinary research (Prusinkiewicz, 2004). However, it would not be possible, if not for information and computer systems evolution, which enabled the knowledge synthesis in physiological processes of plants and explanation of crop functioning as an integrated whole.

Classical growth models, inter alia, logisitc, Gompertz and Richards equations are widely and often used for description of biological processes (Werker and Jaggard, 1997). Many of these equations define sigmoid curves, in which the growth rate raises along with the increase of the size (from low values to the maximum in situ point and then reduces to zero in the upper asymptote) (Ratkowsky, 1983). Biologists, the most often used models, such as logistic functions, Gompertz or monomolecular, which have only three parameters (if it is assumed that the minimum value is 0) (Zeide, 1993; Birch, 1999).

In order to predict the biological systems development many models were introduced. They are related to the population dynamics differently. This may be discreet modelling or in case of big populations, continuous. Many papers inform that the simple exponential model may ensure proper approximation of the growth in the initial period. However, in this case, for example inter-species competition is not included. In this situation, population would still be growing without any impediments (or inevitably would drop to zero, if initial reduction of the growth would have taken place). Even if the impact of limiting factors would be omitted, the model does not include the growth reduction due to inter-species 
Concepts and methods ... - Part I

competition for environmental resources. In case of per se growth, unlimited growth is also unrealistic, for example, when plants will get close to maturity, their physical properties will achieve a limiting dimension. Even Verhulst (1838) decided that for the model a stable population would consequently have the feature of the saturation level. Such state of affairs is usually called carrying capacity $\mathrm{K}$ and constitutes a numerical limitation of the growth size. Thus, he introduced a logistic growth equation in order to ensure extension of the exponential model. Regardless this limitation, logistic equation of the growth was used for modelling many various biological systems (Tsoularis and Wallace, 2002).

\section{Seeds germination modelling}

Germination is a key element of seedlings formation. It is a constant and non-reversible process, which starts from various physiological activities in seeds and after its beginning, a germ will experience growth or death. However, according to Bewley and Black (1994) a definition of germination is often used informally and even incorrectly, which is confused with the seedlings growth, which starts when the germination process is completed. In a practical sense, it is hard to define the beginning and the end of each process, of partial germination, since molecular and cellular events are engaged in multi-cell and complex tissues and the process reactivation takes place gradually (Ranal and Santana, 2006; Fenner and Thompson, 2005). Finding out what determines the germination phenomenon in the nature, is still a constant research objective (Baskin and Baskin, 1998).

However, germination is a rarely immediate phenomenon. Each single seed within population has a unique genotype and this genotype may affect the seeds reaction to environmental stimuli.

Methods of germination dynamics analysis of various seeds have been developing very dynamically in the recent years (Garcia-Huidobro et al., 1982; Ellis et al., 1986; Bradford, 1995).Within the last two centuries several methods or mathematical expressions for measurements of the germination process were suggested or discussed. On one hand, it is favourable, and on the other, variety of expressions impedes a comparison. A few of those expressions have the same name, and measure various features of the germination process, some of them have the same meaning, although they are expressed with various symbols, while various mathematical words are used for the measurement of the same characteristics (Ranal and Santana, 2006). Time, speeds, homogeneity and synchronization are important aspects that inform on the dynamics of the process. These properties are important not only for physiologists and seeds technologies but also for ecologists, because one may predict the degree of the success of the species based on the seeds ability to growth and develop in time.

The main factors that regulate the seeds germination are temperature, water potential of the environment and air quality (Roberts, 1988; Roberts and Ellis, 1989; Bradford, 1995).

In case of majority of seeds, a time pattern of their germination is strictly regulated with soil water potential of the environment, since it determines the equilibrium water content in seeds (Daws et al., 2008; Mesgaran et al., 2012). Germinating seeds have a great sensitivity to thermal and hydrological conditions as well as clearly and immediately react to any external physical factors (e.g. soil temperature change). Ability to predict time of seedling 
occurrence becomes an indispensable element of the integrated system of crop production management.

More and more attention is paid to this issue in the last years. Not without the meaning is active support of specialists from other scientific fields (Hageseth and Joyner, 1975; Shafii et al., 1991; Shafii and Price, 2001; Odabas and Mut, 2007; Tjørve and Tjørve, 2010). Since, the germination period and the period of seedling growth is the most deadly for them (Fellner and Sawhney, 2001) optimization of mechanisms that control the beginning of germination and its course, may ensure seedlings with bigger chances of survival and significantly affect the final quality of yields and their market value (Finch-Savage and Phelps, 1993; Mesgaran et al., 2012).

Fast and homogeneous seeds germination provides advantages both economic and environmental ones in agriculture, since it enables the increase of the production automation degree, control development of weeds and reduce pathogenic factors. It facilitates also introduction and optimization of new technologies of a precise cultivation and plant production. Modelling the seeds germination kinetics is a subject of numerous experimental and theoretical papers. Although, germination is a constant process of changes of biological activities in seeds, in majority of models it is recognised from the practical side. Germination is considered as a fact of visual registration of piercing of germ roots through external layers of fruit and seeds cover. Mathematical models of germination are thus, the most often descriptive models, which give a general image of basic properties of the process dynamics (Ranal and Santana, 2006).

Berry et al., (1988) analysed a possibility of a description of the germination curve generalized in the form of Richards function. From this function, at a correct selection of values of particular parameters of equation, majority of sigmoid functions may be obtained (logistic, autocatalic, Gompertz function, monomolecular and distribuants of the normal and gamma distribution). The obtained results showed that for germination curves of the majority of the investigated crop seeds, the values of the parameters which define the shape of the curve, aimed at the value of allotted Gompertz function and simultaneously it differed in the highest degree from the values corresponding to the logistic function (Muszyński et al., 2015). The germination process was mathematically described also with simulation models, suggested by Gładyszewska and Koper 2002a, Gładyszewska and Koper, 2002b, Gładyszewska, 1998. The mentioned authors assumed that germination has three characteristic stages: physical, biochemical and physiological. It was also assumed that the germination process includes a gradual development through subsequent stages at a given level of probability (Gładyszewska and Ciupak, 2009).

In the literature concerning this issue one may meet analytical (logistic function, Rayleigh distribution, Gauss distribution, Verhulst-Pearl equation) (Glaser, 1975; Gładyszewska, 1998; Pabis, 1985) and simulation ones (Monte Carlo Method) (Gładyszewska, 1998; Gładyszewska and Koper 2002a; Jazwiński et al., 1975; Roe, 1982) seed germination models. Analytical models may be used in a quite extensive mathematical description of seeds germination. They deserve a particular attention in case, when the impact of various external factors on the germination process kinetics is investigated (Gładyszewska et al., 2001).

However, how can we obtain information, when and how many seeds will germinate, in the environment, when we have only imperfect models developed in laboratory conditions. Hydrothermal models constitute a basis for many present efforts for seed germination pre- 
Concepts and methods ... - Part I

diction. A key feature of these models is an assumption that each seed accumulates hydrothermal time in relation to temperature and water potential referred to the base temperature and water potential, at which seeds may grow. The main advantage of hydrothermal models is the fact that their equations refer to the entire population of seeds and lead to simultaneous predictions of germination speed and the interest of germinating seeds (Alvarado and Bradford, 2002; Batlla et al., 2004; Köchy and Tielbörger, 2007; Mesgaran et al., 2012). Often it is not clear, how the experimental data carried out in controlled conditions will refer to the changing field environment. Simulation modelling ensures the best possible hypothesis test that seeds and seedlings integrate in a predictable manner its possible water potential and a thermal history in field conditions. This hypothesis was verified with hydrothermal time concepts for the loss of hybernation of Bromus tectorum seeds ( (Bauer et al., 1998) but so far, not too much attention was paid to it in modelling of occurrence of seedlings (Finch-Savage et al., 1998, Roman et al., 1999). Improvements of hydrothermal modelling suggested by Rowse and Finch-Savage (2003) are becoming parts of papers on germination modelling in field conditions, which leads to considerable progress in development of hydrothermal threshold models, which more precisely predict seeds behaviour in the real environment (Allen, 2003).

It is significant to base on the methods enabling strict description of the germination process both in laboratory conditions as well as field conditions when assessing the germination ability. Such a germination process is possible only when mathematical modelling of the investigated process is applied. Parameters applied in such a model enable obtaining precise relation between the results obtained in a laboratory in field experiments (Gładyszewska, 2004). Some three-parameter growth functions, such as Weibulla function do not need the time constant since they have a zero value in the initial time, as a result they are more elastic on other accounts (Gładyszewska, 2004, Yang et al., 1978). However, since the defined curves defined by those equations are seriously limited, many researchers used equations with additional parameters. So far, Richards equation is more popular among more elastic growth equations. It is preconditioned with the fact that it has an additional shape parameter, and it causes that it may be balanced with logistic equations, Gompertz and monomolecular equations (France and Thornley, 1984). Shape parameter change enables the inflection point of the curve to have any value between the minimum and upper asymptote.

\section{Conclusions}

Seed germination models are still being improved as a result of mechanical integration of microclimate and variables related to the germination speed and seedling elongation. A good introduction to such mechanistic modelling integration with empirical one is research on germination carried out by Benech et al., (1990), Romanet al., (2000). The model from the first research integrates the seeds dormancy, germination and soil temperature. In the second research, dormant cycles of seeds (interrupted with light and temperature), seeds germination, seedlings growth and soil temperature are overlapping. In the third one, soil temperature and water potential are combined in hydrothermal time in order to predict seeds germination and thermal time of estimation of seedling elongation. Although, any of these research does not achieve perfection, they indicate a direction, where emergency 
models must aim. In the meantime, simple but effective empirical models, which combine soil temperature with water potential in soil (Finch-Savage and Phelps, 1993) will have to suffice for the increase of the information resource concerning agronomic management (Forcella, 1998).

Many processes and phenomena which take place in agriculture has a non-linear character, therefore relations inside them are complex and not easy to be formally described. In such situations, often application of traditional methods is difficult, thus, it is more often suggested instead of using modern informative techniques, and in particular procedures that base on artificial intelligence methods. A dynamic progress of computer and informative technologies create new possibilities and directions of development of many scientific fields, including agricultural engineering (Trajer, 2005; Boniecki and Niżewski, 2010). Based on the experiments which were carried out, it was found out that neural techniques are a suitable predictive tool that enables formation of a model for crop prediction (Boniecki and Niżewski, 2010). Although, often application of models is limited, the simulation test constitutes an example of how we can use it. It is a tool, which may supplement field experiments due to the possibility of results generalization. It is almost possible at field experiments only. It also ensures a help in planning subsequent experiments in order to check the real meaning of controlling variables, which are not observed on fields, but are detected by simulation.

On account of a very big number of data, based on which such models should be formed, and also on account of a considerable variability of data within population, it seems that techniques of formation of artificial neural networks may constitute a tool suitable for formation of time models of parameters change (Białobrzeski et. al., 2005).

The objective of the first formed models, called heuristic, was a wider understanding of crops in the aspect of physiological mechanisms of plant growth and development. However, with time, further development of simulation models was possible. Since, it occurred that it is possible to use them for extrapolation and prediction. These models have, thus, become a support with regard to tactical and strategic decisions in management of crops (Rabbinge, 1986, Penning de Vries, 1982). At present, modelling and simulation of plant growth (in particular crops) have become an accepted research tool in agriculture (Rabbinge, 1986; Seligman, 1990). Therefore, extension of knowledge on crops efficiency has become possible through comparison of simulation and experimental observation (Seligman, 1990). Models developed and presented in the research papers may be used not only in the scientific research oriented at application, but also in the application research, where their users may be inter alia managers of agricultural enterprises. However, the fact that so far majority of research that uses crop growth models have concerned the problem of efficiency prediction (Seligman, 1990; Aggarwal, 1993, van Keulen and Stol, 1995) and the impact of climatic changes on plant production (Wolf, 1993, Matthews et al., 1995) should be emphasised.

The plant growth models were applied in plant cultivation for simulation of morphological and physiological changes of plant properties (Donald, 1968) in various environments (Dingkuhn et al., 1993, Hunt, 1993, Kropff et al., 1995). Hunt (1993) and Palanisamy et al. (1993) suggested the use of parametrized crop growth models in field conditions. As a result of such approach, a simulation of long term stability of cultivars cropping in the expected scope of climatic conditions is possible. This technique of mathematical methods gives thus an opportunity to reduce the costs of cultivation programs through reduction of 
the expensive numbers and years, multi-location of field research, which are presently required in order to ensure their statistic credibility.

\section{References}

Aggarwal, P.K. (1993). Agro-ecological zoning using crop growth simulation models: characterization of wheat environments in India. F.W.T. Penning de Vries, P. Teng, K. Metselaar (Eds.), Systems approaches for sustainable agricultural development, Kluwer Academic Publishers, Dordrecht, The Netherlis, 97-109.

Allen, P.S. (2003). When i how many? Hydrothermal models and the prediction of seed germination. New Phytologist 158, 1-9.

Alvarado, V, Bradford, K.J. (2002). A hydrothermal time model explains the cardinal temperatures for seed germination. Plant, Cell \& Environment 25, 1061-1069.

Baskin, C.C, Baskin, J.M. (1998). Seeds - ecology, biogeography, and evolution of dormancy and germination. San Diego, CA, USA: Academic Press.

Batlla, D, Kruk, BC, Benech-Arnold, RL. (2004). Modelling changes in dormancy in weed soil seed banks: Implications for the prediction of weed emergence. In: Benech-Arnold RL, Sanchez RA, eds. Hibook of seed physiology: applications to agriculture. New York, NY, USA: Food Product Press i the Haworth Reference Press, 245-270.

Bauer, M.C., Meyer, S.E., Allen, P.S. (1998). A simulation model to predict seed dormancy loss in the field for Bromus tectorum L. Journal of Experimental Botany 49, 1235-1244.

Benech Arnold, R.L., Ghersa, C.M., Sanchez, R.A., Insausti, P. (1990). A mathematical model to predict Sorghum halepense (L.) Pers. seedling emergence in relation to soil temperature. Weed Research, 30, 91-99.

Berry, G.J., Cawood, R.J., Flood, R.G. (1988). Curve fitting of germination data using the Richards function. Plant, Cell \& Environment, 11, 183-188.

Bewley, J.D., Black, M. (1994). Seeds. Germination, Structure, and Composition. Springer Science+Business Media, LLC, New York.

Białobrzeski, I., Markowski, M., Bowszys, J., Myhan, R. (2005). Symulacyjny model zmian pola temperatury w silosie zbożowym. Inżynieria Rolnicza, 8(68), 23-30.

Birch, C.P.D. (1999). A New Generalized Logistic Sigmoid Growth Equation Compared with the Richards Growth Equation. Annals of Botany, 83, 713-723.

Boniecki, P., Niżewski, P. (2010). Modelowanie neuronowe w rozwiązywaniu wybranych problemów predykcyjnych inżynierii rolniczej. Journal of Research i Applications in Agricultural Engineering, 55(1), 16-19.

Bradford, K.J., (1995). Water relations in seed germination. In: Kigel, J., Galili, G. (Eds.), Seed Development i Germination. Marcel Dekker, New York, pp. 351-396.

Cieśla A., Kraszewski, W., Skowron, M., Syrek P. (2015). Wpływ działania pola magnetycznego na kiełkowanie nasion. Przeglad Elektrotechniczny, 91(1), 125-128

Daws, M.I., Crabtree, L.M., Dalling, J.W., Mullins, C.E., Burslem, D. (2008). Germination responses to water potential in neotropical pioneers suggest large-seeded species take more risks. Annals of Botany 102, 945-951.

De Wit, C.T. (1982). Simulation of living systems. In Simulation of plant growth and crop production, ed. F. W. T. Penning de Vries \& H. H. van Laar. Simulation Monographs, PUDOC, Wageningen, The Netherlis. pp. 3-8.

Dingkuhn, M., Penning De Vries, F.W.T., Miezan, K.M. (1993). Improvement of rice plant type concepts: systems research enables interaction of physiology i breeding. In: Penning de Vries F., Teng P., Metselaar K. (eds) Systems approaches for agricultural development. Systems Approaches for Sustainable Agricultural Development, vol 2. Springer, Dordrecht

Donald, C.M. (1968). The breeding of crop ideotypes. Euphytica, 17, 385-403. 
Ellis, R.H., Covell, S., Roberts, E.H., Summerfield, R.J.(1986). The influence of temperature on seed germination rate in grain legumes. II. Intraspecific variation in chickpea at constant temperatures. Journal of Experimental Botany, 37, 1503-1515.

Fellner, M., Sawhney, V.K. (2001). Seed germination in a tomato male-sterile mutant is resistant to osmotic, salt and low temperature stresses. Theoretical and Applied Genetics, 102, 215-221.

Fenner, M., Thompson, K. (2005). The ecology of seeds. Cambridge. UK: Cambridge University Press.

Finch-Savage, W.E., Bergervoet, J.H.W., Bino, R.J., Clay, H.A., Groot, S.P.C. (1998). Nuclear replication activity during seed-dormancy breakage and germination in the three tree species: Norway maple (Acer platanoides L.), sycamore (Acer pseudoplatanus L.) and cherry (Prunus avium L.). Annals of Botany, 81, 519-526.

Finch-Savage, W.E., Phelps, K. (1993). Onion (Allium cepa L.) seedling emergence patterns can be explained by the influence of soil temperature and water potential on seed germination. Journal of Experimental Botany 44, 407-414.

Forcella, F. (1998). Real-time assessment of seed dormancy and seedling growth for weed management. Seed Science Research, 8, 201-209.

France, J., Thornley, J.H.M. (1984). Mathematical models in agriculture. Butterworths, London

Garcia-Huidobro, J., Monteith, J.L., Squire, G.R. (1982). Time, temperature and germination of pearl millet (Pennisetum typhoides S.H.). 1. Constant temperature. Journal of Experimental Botany, 33, 288-296.

Gładyszewska B. (1998). Ocena wpływu przedsiewnej laserowej biostymulacji nasion pomidorów na proces ich kiełkowania. Rozprawa doktorska. Lublin. Maszynopis.

Gładyszewska B., Koper R. (2002a). Symulacyjny model procesu kiełkowania nasion w ujęciu analitycznym. Inżynieria Rolnicza, 7, 59-63.

Gładyszewska, B., Koper, R. (2002b). Zastosowanie modelowania matematycznego w ocenie żywotności nasion. Inżynieria Rolnicza, 7, 51-57.

Gładyszewska, B. (2004). Matematyczne metody oceny wpływu procesów przedsiewnej stymulacji na kiełkowanie nasion. Acta Agrophysica, 3(3), 443-452.

Gładyszewska, B., Ciupak, A. (2009). Effect of temperature on the viability of buckwheat (cv. Kora) seeds. Teka Komisji Motoryzacji i Energetyki Rolnictwa, 6, 31-39.

Gładyszewska, B., Koper, R., Drabarek, L., Gładyszewski, G. (2001). Analityczne modele procesu kiełkowania nasion. Inżynieria Rolnicza, 2, 57-61.

Glaser, R. (1975). Wstep do biofizyki. PZWL, Warszawa.

Hageseth, G.T., Joyner, R.D. (1975). Kinetics and thermodynamics of isothermal seed germination Journal of Theoretical Biology, 53, 51-65.

Hunt, L.A. (1993). Designing improved plant types: a breeder's viewpoint. In: F.W.T., Penning de Vries F.P., Teng P., Metselaar K. (eds) Systems approaches for agricultural development. Springer, Dordrecht

Jazwiński, J., Pabis, S., Wieremiejczyk, W. (1975). Symulacyjne metody badań niezawodności systemów technicznych. Materiały na „Szkołę Zimową -75”. Jaszowiec, 13-18 stycznia 1975, Katowice.

Keller, E.F. (2002). Making Sense of Life. Explaining Biological Development with Models, Metaphors, and Machines. Cambridge, MA: Harvard University Press.

Köchy, M., Tielbörger, K. (2007). Hydrothermal time model of germination: parameters for 36 Mediterranean annual species based on a simplified approach. Basic and Applied Ecology, 8,171-182.

Kropff, M.J., Haverkort, A.J., Aggarwal, P.K., Kooman, P.L. (1995). Using systems approaches to design and evaluate ideotypes for specific environments. J. Bouma, A. Kuyvenhoven, B.A.M. Bouman, J.C. Luyten, H.G. Zistra (Eds.), Eco-regional approaches for sustainable li use and food production, Kluwer Academic Publishers, Dordrecht, The Netherlis, 417-435.

Maksym, P., Marciniak, A.W., Kostecki, R. (2006). Zastosowanie sieci bayesowskich do modelowania rolniczego procesu produkcyjnego. Inżynieria Rolnicza, 12, 321-330.

Matthews, R.B., Kropff, M.J., Bachelet, D., van Laar, H.H. (1995). Modelling the impact of climate change on rice production in Asia. CAB International, Wallingford, UK. 
Concepts and methods ... - Part I

Mesgaran, M.B., Mashhadi, H.R., Alizadeh, H., Hunt, J., Young, K.R., Cousens, R.D. (2012). Importance of distribution function selection for hydrothermal time models of seed germination. Weed Research, 53, 89-101.

Michałek, R. (20018). Przyszłość inżynierii rolniczej jako nauki i kierunku kształcenia. Inżynieria Rolnicza, 1(99), 297-302.

Minorsky, P.V. (2003). Achieving the in silico plant. Systems biology and the future of plant biological research. Plant Physiolgy, 132, 404-409.

Muszyński, S., Świetlicka, I., Świetlicki, M., Gładyszewska, B. (2015). Modelowanie kinetyki kiełkowania nasion pomidora z wykorzystaniem równania Gompertza. Acta Scientiarum Polonorum Technica Agraria, 14(1-2), 61-69.

Niklas, K. (2003). The bio-logic and machinery of plant morphogenesis. American Journal of Botany, 90, 515-525.

Odabas, M.S., Mut, Z. (2007). Modelling the effect of temperature on percentage and duration of seed germination in grain legumes and cereals. American Journal of Plant Physiology, 2, 303-310.

Pabis, S. (1985). Metodologia i metody nauk empirycznych. PWN, Warszawa.

Palanisamy, S., Penning de Vries, F.W.T., Mohiass, S., Thiyagarajan, T.M., Kareem A.A. (1993). Simulation in pre-testing of rice genotypes in Tamil Nadu. F.W.T. Penning de Vries, P. Teng, K. Metselaar (Eds.), Systems approaches for sustainable agricultural development, Kluwer Academic Publishers, Dordrecht, The Netherlis, 63-75.

Penning de Vries, F.W.T. (1982). Simulation of Plant Growth and Crop Production. Van Laar H.H. (Eds.), Simulation Monographs, Pudoc, Wageningen, The Netherlis.

Prusinkiewicz, P. (2004). Modeling plant growth and development. Current Opinion in Plant Biology, 7, 79-83.

Rabbinge, R. (1986). The bridge function of crop ecology. Netherlis Journal of Agricultural Sciences, $34,239-251$

Ranal, M.A., Santana, D.G. (2006). How and why to measure the germination process. Revista Brasileira de Botânica, 29, 1-11.

Ratkowsky, D.A., Lowry, R.K., McMeekin, T.A., Stokes, A.N., Chiler, R.E. (1983). Model for bacterial culture growth rate throughout the entire biokinetic temperature range. Journal of bacteriology, 154(3), 1222-1226

Roberts, E.H. (1988). Temperature and seed germination. In: Long, S.P., Woodword, F.I. (Eds.), Plants and Temperature. Society for Experimental Biology. Company of Biologists, Cambridge.

Roberts, E.H., Ellis, R.H. (1989). Water and seed survival. Annals of Botany, 63, 39-52.

Roe B. P. (1992). Probabilistic and statistics in experimental physics. Springer-Verlag, New York.

Roman, E.S., Murphy, S.D., Swanton, C.J. (2000). Simulation of Chenopodium album Seedling Emergence. Weed Science, 48, 217-224

Roman, E.S., Thomas, A.G., Murphy, S.D., Swanton, C.J. (1999). Modelling germination and seedling elongation of common lambsquarters (Chenopodium album). Weed Science, 47, 149-155.

Room, P., Hanan, J., Prusinkiewicz, P. (1996). Virtual plants: new perspectives for ecologists, pathologists and agricultural scientists. Trends in Plant Science, 1, 33-38.

Rowse, H.R., Finch-Savage, W.E. (2003). Hydrothermal threshold models can describe the germination response of carrot (Daucus carota) and onion (Allium cepa) seed populations across both sub- and supra-optimal temperatures. New Phytologist, 158, 101-108.

Seligman, N.G. (1990). The crop model record: promise or poor show? R. Rabbinge, J. Goudriaan, H. van Keulen, F.W.T. Penning de Vries, H.H. van Laar (Eds.), Theoretical Production Ecology: Reflections and Prospects, PUDOC, Wageningen, pp. 249-258.

Shafii, B., Price, W.J., Swensen, J.B., i Murray, G.A. (1991). "Nonlinear Estimation of Growth Curve Models for Germination Data Analysis," in Proceedings of the 1991 Kansas State University Conference on Applied Statistics in Agriculture, G. A. Milliken i J. R. Schwenke (eds.), Manhattan, KS: Kansas State University, 19-42. 
Shafii, B., Price, W.J. (2001). Estimation of cardinal temperatures in germination data analysis. Journal of Agricultural, Biological and Environmental Statistics, 6, 356-366

Tjørve, E., Tjørve, K.M.C. (2010). A unified approach to the Richards-model family for use in growth analyses: why we need only two model forms. Journal of Theoretical Biology, 267, 417-425.

Trajer, J. (2005). Sztuczne sieci neuronowe w modelowaniu procesów z ograniczonym zbiorem danych w inżynierii rolniczej. Inżynieria Rolnicza, 2(62), 55-61.

Tsoularis, A., Wallace J. (2002). Analysis of logistic growth models. Mathematical Biosciences, 179, 21-55.

Van Keulen, H., Stol, W. (1995). Agro-ecological zonation for potato production. A.J. Haverkort, D.K.L. Mackerron (Eds.), Potato ecology and modelling of crops under conditions limiting growth, Kluwer Academic Publishers, Dordrecht, The Netherlis (1995), pp. 357-371.

Verhulst, P.F. (1838). Notice sur la loi que la population suit dans son accroissement. Correspondence Mathematique et Physique, 10, 113.

Werker, A.R., Jaggard, K.W. (1997). Modelling Asymmetrical Growth Curves that Rise and then Fall: Applications to Foliage Dynamics of Sugar Beet (Beta vulgaris L.). Annals of Botany, 79, 657-665.

Wolf, J. (1993). Effects of climate change on wheat production potential in the European Community. European Journal of Agronomy, 2, 281-292.

Yang, R.C., Kozak, A., Smith, J.H.G. (1978). The potential of Weibull-type functions as flexible growth curves. Canadian Journal of Forest Research, 8, 424-431.

Zeide, B. (1993). Analysis of growth equations. Forest Science, 39, 594-616.

\section{KONCEPCJE I METODY MODELOWANIA MATEMATYCZNEGO PROCESÓW WZROSTU I ROZWOJU ROŚLIN. KIELKOWANIE ROŚLIN - CZĘŚĆ I}

Streszczenie. Nowoczesna inżynieria rolnicza, szuka „bezpiecznych” metod podwyższania jakośc plonów roślin uprawnych, wykorzystując powiązanie wiedzy z wielu nauk. W ten zakres wpisuje się zatem modelowanie komputerowe wzrostu i rozwoju roślin, ponieważ stało się to obszarem badań interdyscyplinarnych. Przedstawienie wiedzy w postaci matematycznych modeli komputerowych jest jednym z paradygmatów systemów produkcji rolniczej opartych na wiedzy naukowej i praktycznej oraz informacji. W działalności naukowej w obszarze inżynierii rolniczej realizuje się już od wielu lat zadania badawcze związane z matematycznym modelowaniem procesów agrobiologicznych. Dodatkowo stosowanie nowoczesnych technik prognozowania w rolnictwie może przynieść realne korzyści finansowe, ze względu na fakt, iż na podstawie prognozowania plonu roślin uprawnych możliwe jest szacowanie opłacalności ich uprawy. Dynamiczny i ciągły postęp technologii komputerowych oraz informacyjnych kreuje nowe możliwości wytyczając tym samym kierunki rozwoju inżynierii rolniczej. Mając to na uwadze należy podkreślić, że modelowanie matematyczne stanowi wsparcie procesów decyzyjnych zachodzących w produkcji rolniczej. W artykule tym omówione zostały modele matematyczne, w których analizowany system jest opisany przy zastosowaniu formuł matematycznych. Celem pracy było przedstawienie dotychczasowego stanu wiedzy na temat metod matematycznych w opisywaniu i prognozowaniu kiełkowania nasion. Przedstawiono możliwości ich wykorzystania i nowe wyzwania pojawiające się w opisie kiełkowania nasion.

Słowa kluczowe: modelowanie w rolnictwie, symulacje komputerowe, modelowanie matematyczne, kiełkowanie 